\title{
Farmers' Perceptions Study on Required Supports for Climate Change Adaptation in Malaysia
}

\author{
Md. Mahmudul Alam * \\ PhD Student \\ Institute for Environment and Development (LESTARI) \\ National University of Malaysia (UKM) \\ E-mail: rony000@gmail.com \\ Chamhuri Siwar \\ Emeritus Professor \\ Institute for Environment and Development (LESTARI) \\ National University of Malaysia (UKM), Malaysia \\ E-mail: csiwar@ukm.my \\ Basri Talib \\ Associate Professor \\ Faculty of Economics and Management \\ National University of Malaysia (UKM), Malaysia \\ E-mail: basri@ukm.my \\ Abdul Hamid Jaafar \\ Professor \\ Faculty of Economics and Management \\ National University of Malaysia (UKM), Malaysia \\ E-mail: ahamid@ukm.my \\ Mohd Ekhwan Toriman \\ Associate Professor \\ School of Social, Development \& Environmental Studies (FSSK) \\ National University of Malaysia (UKM), Malaysia \\ E-mail: $\underline{\text { kkhwan@ukm.my }}$ \\ * Corresponding author
}

\section{Citation Reference:}

Alam, M.M., Siwar, C., Talib, B., Jaafar, A.H., and Mohd Ekhwan, T. 2012. Farmers' Perceptions Study on Required Supports for Climate Change Adaptation in Malaysia, Asian Journal of Environmental and Disaster Management, Vol. 4(1). pp. 83-97. Available at < http://www.rpsonline.com.sg/journals/101-ajedm/2012/0401/S179392402012001081.php >

This is a pre-publication copy.

The published article is copyrighted by the publisher of the journal. 


\title{
Farmers' Perceptions Study on Required Supports for Climate Change Adaptation in Malaysia
}

\author{
Md. Mahmudul Alam, Chamhuri Siwar, Basri Talib, Abdul Hamid Jaafar, Mohd Ekhwan \\ Toriman
}

\begin{abstract}
The agriculture of Malaysia is one of the most vulnerable sectors due to the rapid changes in climatic factors in Malaysia. In order to face and manage the situation, farmers are trying in various ways and government and other external agencies are providing several supports to adapt to these climatic vulnerabilities. Still, there is a gap between farmers' adaptability and adverse impacts of climatic change. Here, sustainability of agriculture and relevant livelihood is strongly dependent on the external supports, and farmers also expect to increase this level. Now, the focus on farmers' adaptability to climate change needs to go beyond the incentive and subsidy. They also need trainings, conceptual supports, and technological innovations. This study finds out the required supports that farmers need to adapt to climate change through a questionnaire survey on 198 paddy producing farmers in the area of Integrated Agricultural Development Area (IADA), North-West Selangor, Malaysia. The data of the study has been analyzed by descriptive statistics, ordered regression, percentile, and scale analysis. The findings of the study are important for the policy makers and relevant agencies.
\end{abstract}

Key words: Agricultural Productivity; Climate change; Adaptation; Paddy; Malaysia

JEL Code: C21, Q14, Q15, Q16, Q18, Q54, Q55

\section{Introduction}

The climatic factors have been changing very rapidly in Malaysia. The average temperature in the rice growing areas in Malaysia is about $26^{\circ} \mathrm{C}$. Under the current climatic change scenario, temperatures above $25^{\circ} \mathrm{C}$ may cause a decline in grain mass by $4.4 \%$ per $1{ }^{\circ} \mathrm{C}$ rise in temperature (Tashiro and Wardlaw 1989) and grain yield may decline as much as $9.6-10.0 \%$ per $1^{\circ} \mathrm{C}$ rise (Baker and Allen 1993). Singh et al. (1996) showed that in Malaysia the actual yield of paddy rice per hectare varied from 3-5 tons, when the potential yield could be 7.2 tons. There is a decline of paddy rice yield between $4.6-6.1 \%$ per $1{ }^{\circ} \mathrm{C}$ temperature increase under the present $\mathrm{CO}_{2}$ level. However, a doubling of $\mathrm{CO}_{2}$ concentration (from present level of 340-680 ppm) may offset the detrimental effect up to $4^{\circ} \mathrm{C}$ temperature increase. In a recent study, it was found that a $1 \%$ increase in temperature leads to a $3.44 \%$ decrease in current paddy yield and $0.03 \%$ decrease in paddy yield in the follwing season; and a $1 \%$ increase in rainfall leads to $0.12 \%$ decrease in current paddy yield and $0.21 \%$ decrease of paddy yield in the following season (Alam et al. 2010c).

Tisdell (1996) found that rainfall variability increased the level of environmental stress which adversely affects the ability of the system to maintain productivity. It is projected that in Malaysia any change in rainfall, both positive and negative, by more than only $0.4 \%$ by 2020 will cause a decline in paddy yield (NRS 2001). Alam et al. (2011a) indicated that the yearly total rainfall is increasing and its monthly variation is too high. The adverse effects of lower rainfall can be reduced or averted by introducing proper irrigation 
systems. However, the effect of the opposite phenomenon of over rainfall especially at the end of the crop cycle or at the maturity period is absolutely uncontrollable.

Over the last 5 years, climate change induced vulnerability of the agricultural factors like injurious insects, high temperature, soil fertility loss, and cost of input materials increased greatly, and the vulnerability of the factors like shortage of rainfall or excessive rainfall increased moderately in Malaysia (Alam et al. 2011b). The climatic factors affect, directly or indirectly, the social and economic sustainability of the farmers. Climate changes cause crop damages, low productivity and high production cost that lead to income losses of farmers, poverty level increases, and seasonal unemployment rate increase (Alam et al. 2010d; Siwar et al. 2009). As farmers are dependent on agriculture, when the profitability and quantity of agricultural production decline, the income of the farmers also declines. In Malaysia, the most possible vulnerable states in terms of poverty are Sabah (23\%), Terengganu (15.4\%), Kelantan (10.6\%), Sarawak (7.5\%), Kedah (7\%), Perlis $(6.3 \%)$ and Perak (4.9\%), where the projected temperature and rainfall changes are also very high (Ninth Malaysia Plan 2006, NAHRIM 2006). It also showed that the most vulnerable groups of people are the poor and hardcore poor having relatively larger household members and being involved in agricultural activities (NRS 2001).

As climatic change is a continuous process, its effects and solutions are also similarly time and effort consuming processes. Most of the global warming during the next 30 years will be due to emissions that have already occurred (Stern 2007). Due to high greenhouse gas emissions the temperature is projected to rise by $0.3-4.5^{\circ} \mathrm{C}$. Warmer temperatures will cause the sea level to rise by about $95 \mathrm{~cm}$ over a hundred-year period. The changes in rainfall may fluctuate from about -30 to $+30 \%$. This change will reduce crop yield. It may cause drought in many areas so that cultivation of some crops such as rubber, oil palm, and cocoa will not be possible (NRS 2001). NAHRIM projection shows maximum monthly precipitation will increase up to $51 \%$ in Pahang, Kelantan, and Terengganu, and the minimum precipitation will decrease by $32-61 \%$ for the entire Peninsular Malaysia. Consequently, annual rainfall will increase by $10 \%$ in Kelantan, Terengganu, Pahang and North-West Coast and decrease by $5 \%$ in Selangor and Johor (NAHRIM 2006). This variation in climatic factors will cause the agricultural system to become vulnerable to risk and uncertainty.

Adaptation strategies are crucial for vulnerable groups because failure to adapt could lead to "significant deprivation, social disruption and population displacement, and even morbidity and mortality" (Downing et al. 1997). The most critical problem is to identify the appropriate adaptation policies that favour the most vulnerable groups. It needs to carefully consider that adaptation for climate change does not ensure equal benefits everywhere and win-win situations are unlikely among stakeholders, and many cases deal with conflicting interest groups. To adapt farmers to the changes, currently government and other external agencies are providing several supports, but still there is a gap between farmers' adaptability to climate change and available supports (Alam et al. 2011d, e, f). Here, sustainability of agriculture and relevant livelihood is strongly dependent on the external supports, and farmers also expect to increase this level. Thus, the paper is an attempt to find out other required supports for farmers to adapt to climate changes in perspective of Malaysia.

\section{Data, Model and Methodology}

To determine the climate change adaptation of the farmers in Malaysia, this study relies on primary data from a research project entitled "The economics of climate change: Economic 
dimensions of climate change, impacts and adaptation practices in agriculture sector: Case of paddy sector in Malaysia", conducted by the Institute for Environment and Development (LESTARI) of the National University of Malaysia (UKM) funded by Ministry of Science, Technology and Environment of the Government of Malaysia (Alam et al. 2010a). Data for this project were collected through a sample survey of paddy producing farmers in the eight sections of the Integrated Agricultural Development Area (IADA) of North-West Selangor, Malaysia (Figure 1). Geographically, the agricultural land of IADA in North-West Selangor covers an area of 100,000 hectares (ha), with 55,000 ha used for palm oil, 20,000 ha for coconut, 5,000 ha for fruits and vegetables and 20,000 ha for paddy. This 20,000 ha for the paddy area includes major rivers, i.e Sungai Sireh and Sungai Karang, a $75 \mathrm{~km}$ irrigation system, and other infrastructures. The total paddy producible area is 18,638 ha, and currently paddy is planted on 18,355 ha. Total paddy irrigated area is 18,980 ha, with the additional 625 ha being used for drainage. There are a total of 10,300 paddy farmers and 30,000 other crops producers. The total size of the agricultural community is 50,000.

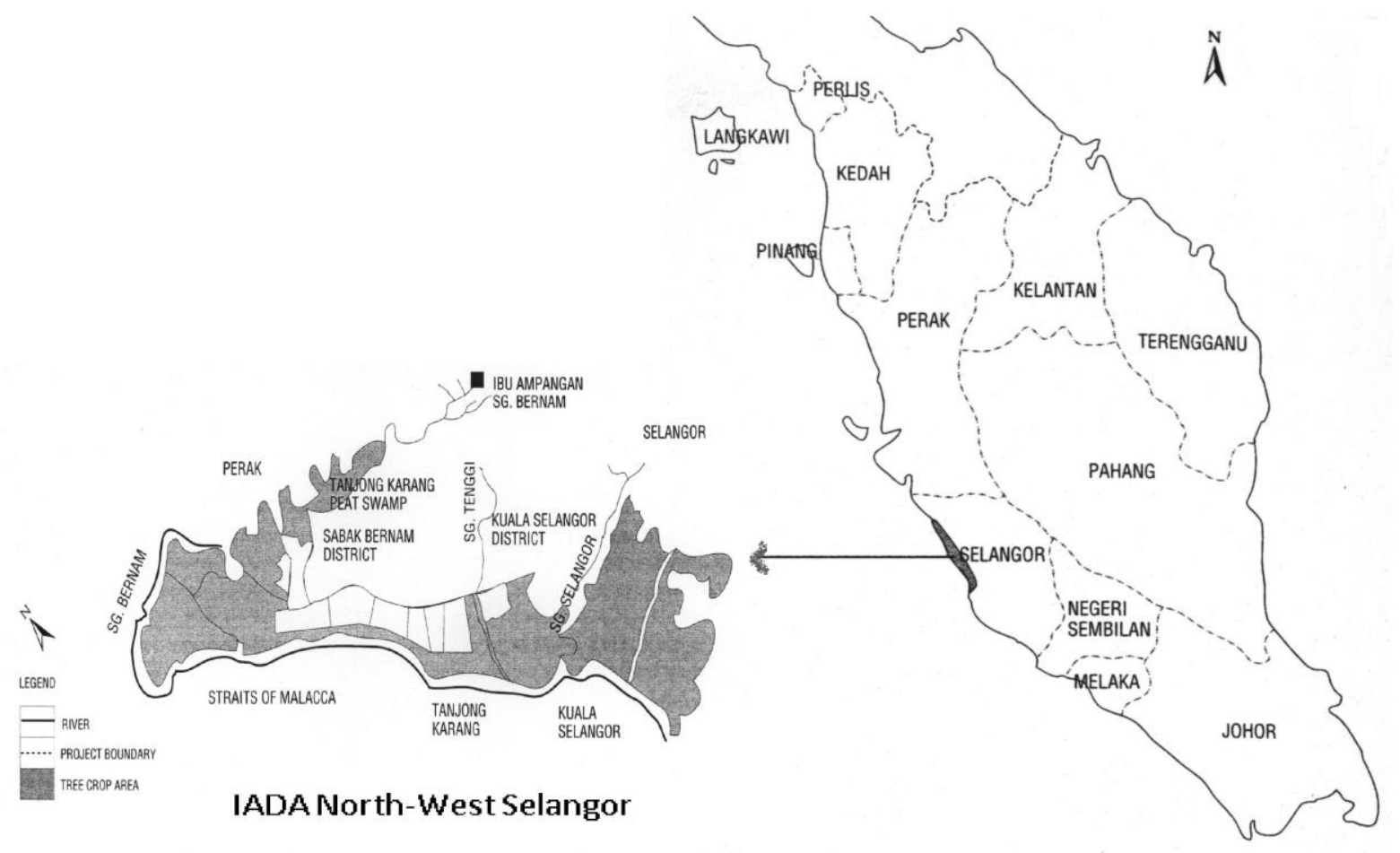

Figure 1: Location of study area, IADA in North-West Selangor, Malaysia

The target group of the survey was paddy producing farmers. The survey was conducted by regular enumerators of the IADA authority using a structured questionnaire under the direct supervision of IADA officials. The population size of the area was 10,300 while the sample for the study consisted of 198 respondents proportionately distributed among the eight areas based on the size of the irrigated land area. The 198 households covered 577.53 ha of paddy areas. The sample within the area is selected randomly. Details of socioeconomic profiles of the respondents are available at Alam et al. (2010b, d, 2011c).

To determine the relationships between the adaptation ability of the farmers and required external supports to cope with climate change properly, this study ran an ordered dependent regression/ ordinal regression. 
$\mathrm{Q}_{1}=\beta_{1} \mathrm{~V}_{1}+\beta_{2} \mathrm{~V}_{2}+\beta_{3} \mathrm{~V}_{3}+\beta_{4} \mathrm{~V}_{4}+\beta_{5} \mathrm{~V}_{5}+\beta_{6} \mathrm{~V}_{6}+\beta_{7} \mathrm{~V}_{7}+\beta_{8} \mathrm{~V}_{8}+\beta_{9} \mathrm{~V}_{9}+\beta_{10} \mathrm{~V}_{10}+$ $\beta_{11} \mathrm{~V}_{11}+\beta_{12} \mathrm{~V}_{12}+\beta_{13} \mathrm{~V}_{13}+\beta_{14} \mathrm{~V}_{14}+\beta_{15} \mathrm{~V}_{15}+\varepsilon_{\mathrm{i}}$

Here,

$\mathrm{Q}_{1}=$ Farmers' capability to adapt to climate change (ordinal data)

$\mathrm{V}_{1}=$ Water management innovations is required to cope with climate change effect (ordinal data)

$\mathrm{V}_{2}=$ Irrigation system innovations is required to cope with climate change effect (ordinal data)

$\mathrm{V}_{3}=$ Moisture deficiency relevant innovations is required to cope with climate change effect (ordinal data)

$\mathrm{V}_{4}=$ Crop development is required to cope with climate change effect (ordinal data)

$\mathrm{V}_{5}=$ Early warning about weather and climate information is required to cope with climate change effect (ordinal data)

$\mathrm{V}_{6}=$ Daily and seasonal weather forecasts is required to cope with climate change effect (ordinal data)

$\mathrm{V}_{7}=$ Proper guidelines or suggestion is required to cope with climate change effect (ordinal data)

$\mathrm{V}_{8}=$ Raw materials subsidy is required to cope with climate change effect (ordinal data)

$\mathrm{V}_{9}=$ Cash incentive is required to cope with climate change effect (ordinal data)

$\mathrm{V}_{10}=$ Insurance support is required to cope with climate change effect (ordinal data)

$\mathrm{V}_{11}=$ Infrastructural support, such as irrigation and transportation, is required to cope with climate change effect (ordinal data)

$\mathrm{V}_{12}=$ Diversify crop types and varieties is required to cope with climate change affect (ordinal data)

$\mathrm{V}_{13}=$ Adjustment in land use pattern is required to cope with climate change effect (ordinal data)

$\mathrm{V}_{14}=$ Adjustment in wage and leasing system is required to cope with climate change effect (ordinal data)

$\mathrm{V}_{15}=$ Merge individual farmers to farm is required to cope with climate change effect (ordinal data)

$\beta=$ Coefficient of respective explanatory variable

$\varepsilon_{\mathrm{i}}=$ Independent and identically distributed random variables

\section{Government Supports for Adaptation}

Currently, government of Malaysia provides huge amounts of subsidy to the paddy producers to encourage paddy cultivation and to ensure more production for increasing the country's self-sufficiency level. The types and contents of these subsidies have been summarized below:

- Input subsidy: 12 bags (20 kg each) of compound fertilizer and 4 bags (20kg each) of urea fertilizer per hectare - worth MYR 400 and pesticide incentive worth MYR 200 per hectare.

- Price subsidy: Provided at the selling price - MYR 248.1 per ton.

- Rice production incentive: Land preparation/plowing incentive - MYR 100 per hectare and organic fertilizer 100kg per hectare - worth MYR 140.

- Yield increase incentive: Provided if producers (farmers) are able to produce 10 tons or more per hectare - MYR 650 per ton. 
- Free supports: Free supports for irrigation, infrastructure, and water supply.

In order to support the farmers and increase productivity as well as increase income of farmers, government's subsidy for agricultural sector is increasing each year (Table 1). The subsidies for urea and compound fertilizer have been continuing since 1979. The incentive for land preparation and using organic fertilizer has been continuing since 2007. Providing compound and urea fertilizers and pesticide incentives was introduced in 2008 and is still continuing.

Table 1: Government Subsidy (in MYR) for Paddy Sector in Malaysia

\begin{tabular}{lrrrr}
\hline Items & 2004 & 2005 & 2006 & 2007 \\
\hline \hline Subsidy For Paddy Price & $476,628,303$ & $443,218,042$ & $445,749,898$ & $444,000,000$ \\
Paddy Fertilizers & $186,744,867$ & $178,072,073$ & $396,393,001$ & $261,677,743$ \\
Paddy Production Incentive & NA & NA & NA & $67,563,904$ \\
Yield Increase Incentive & NA & NA & NA & $85,434,620$ \\
Paddy Seed Help & NA & NA & NA & $17,000,000$ \\
Diesel Subsidy Scheme & NA & NA & $989,727,418$ & $1,099,000,723$ \\
Petrol & NA & NA & $45,413,959$ & $69,461,384$ \\
\hline Total Subsidy and Incentive & $663,373,170$ & $621,290,115$ & $1,877,284,276$ & $2,044,138,374$ \\
\hline
\end{tabular}

Note: NA for data which were not found available.

Source: Agriculture Statistical Handbook 2008

\section{Required Supports for Adaptation}

Farmers take various types of measures to adapt to the climatic vulnerabilities. Their approaches vary based on their perceptions, knowledge, locations, availability of resources, cropping patterns, nature and degree of vulnerability, etc (Alam et al. 2011f). Now, farmers need several types of external supports to cope properly with the changes in climate factors. To check the relationship between farmers' ability to adapt and required external supports to adapt to climate change, this study ran an ordinal regression. The P-value (.000038) of LR stat shows a very good fit of the model. The output of the regression shows, among several types of external supports, farmers significantly need moisture deficiency related innovations, crop development, cash incentive, infrastructural supports, and adjustment in wage and leasing systems to adapt to climate change. However, the necessity of extra supports in respect to their current ability to adapt shows a very low odd ratio indicating that these supports are currently not influencing the farmers' adaptation ability. These supports might be related to their future adaptation ability. Individual requirement analysis will give a clearer picture in this regard.

Table 2: Statistical Output for Farmers' Ability of Adaptation on Required Supports

\begin{tabular}{lccccc}
\hline Category of Supports & $\begin{array}{c}\text { Independent } \\
\text { Variables }\end{array}$ & Coefficient & z-stat & P-value & $\begin{array}{c}\text { Odd } \\
\text { Ratio }\end{array}$ \\
\hline \hline & V1 & 0.126 & 0.586 & 0.558 & 1.135 \\
Innovation Related & V2 & -0.153 & -0.706 & 0.480 & 0.858 \\
Supports & V3 & $0.263 \sim$ & 1.912 & 0.056 & 1.301 \\
& V4 & $-0.200 \sim$ & -1.744 & 0.081 & 0.819 \\
\hline Information Related & V5 & 0.068 & 0.502 & 0.616 & 1.071 \\
Supports & V6 & 0.025 & 0.189 & 0.850 & 1.026
\end{tabular}




\begin{tabular}{lccccc} 
& V7 & -0.207 & -1.365 & 0.172 & 0.813 \\
\hline \multirow{2}{*}{ Financial Supports } & V8 & 0.086 & 0.579 & 0.562 & 1.090 \\
& V9 & $0.596^{*}$ & 3.642 & 0.000 & 1.815 \\
& V10 & -0.206 & -1.468 & 0.142 & 0.814 \\
\hline Encouraging Supports & V11 & $-0.478^{*}$ & -2.622 & 0.009 & 0.620 \\
\hline \multirow{3}{*}{ Production Practice } & V12 & -0.139 & -1.242 & 0.214 & 0.870 \\
Related Supports & V13 & 0.198 & 1.298 & 0.194 & 1.219 \\
& V14 & $0.297^{\wedge}$ & 2.527 & 0.012 & 1.345 \\
& V15 & 0.130 & 1.250 & 0.211 & 1.138 \\
\hline
\end{tabular}

$*, \wedge$, and $\sim$ are significant at the $1 \%, 5 \%$ and $10 \%$ significance level, respectively

Note: The Odd ratio is calculated as $\mathrm{e}^{\wedge} \beta$

As the needs of farmers differ from person to person, more in-depth and specific requirement is required to measure by category and individual type of variable analysis. Among all types of resource management innovations, water management innovation, irrigation system innovation and moisture deficiency protection related innovation are important to adapt to climate change. $70.7 \%$ of the farmers expect water management innovation to cope with climate change, whereas only $8.1 \%$ disagree. Further, $70.2 \%$ of the farmers mentioned that irrigation system innovation is required to adapt to climate change, whereas only $7.1 \%$ disagreed. Furthermore, $72.2 \%$ of the farmers need moisture deficiency protection innovations, while only $4.5 \%$ mentioned that it is not important. Developing new crops or innovation of climate change tolerant crops are needed by $68.7 \%$ of the farmers, while only $9.1 \%$ think it is not important to cope with changing climate factors.

Table 3: Innovation and Information Related Required Supports for Adaptation to Climate Change

\begin{tabular}{|c|c|c|c|c|c|c|c|c|c|}
\hline \multirow{2}{*}{$\begin{array}{l}\text { Types of } \\
\text { Supports }\end{array}$} & \multicolumn{5}{|c|}{ Observation Scale* } & \multirow{2}{*}{$\begin{array}{l}\text { Average } \\
\text { Value } \\
\text { of Scale }\end{array}$} & \multirow{2}{*}{ S.D. } & \multirow{2}{*}{$\begin{array}{c}\text { Agreed } \\
\text { (4 and 5) } \\
\text { Observation }\end{array}$} & \multirow{2}{*}{$\begin{array}{c}\text { Disagreed } \\
(1 \text { and 2) } \\
\text { Observation }\end{array}$} \\
\hline & 1 & 2 & 3 & 4 & 5 & & & & \\
\hline $\begin{array}{l}\text { Water management } \\
\text { Innovations }\end{array}$ & $\begin{array}{c}5 \\
2.5 \%\end{array}$ & $\begin{array}{c}11 \\
5.6 \%\end{array}$ & $\begin{array}{c}42 \\
21.2 \%\end{array}$ & $\begin{array}{c}40 \\
20.2 \%\end{array}$ & $\begin{array}{c}100 \\
50.5 \%\end{array}$ & 4.11 & 1.08 & $\begin{array}{c}140 \\
70.7 \%\end{array}$ & $\begin{array}{c}16 \\
8.1 \%\end{array}$ \\
\hline $\begin{array}{l}\text { Irrigation System } \\
\text { Innovations }\end{array}$ & $\begin{array}{l}5 \\
2.5 \%\end{array}$ & $\begin{array}{c}9 \\
4.5 \%\end{array}$ & $\begin{array}{c}45 \\
22.7 \%\end{array}$ & $\begin{array}{c}40 \\
20.2 \%\end{array}$ & $9950 \%$ & 4.11 & 1.06 & $\begin{array}{c}139 \\
70.2 \%\end{array}$ & $\begin{array}{c}14 \\
7.1 \%\end{array}$ \\
\hline $\begin{array}{l}\text { Moisture Deficiency } \\
\text { Related Innovations }\end{array}$ & $\begin{array}{c}4 \\
2 \%\end{array}$ & $\begin{array}{l}5 \\
2.5 \%\end{array}$ & $\begin{array}{c}46 \\
23.2 \%\end{array}$ & $\begin{array}{c}72 \\
36.4 \%\end{array}$ & $\begin{array}{c}71 \\
35.9 \%\end{array}$ & 4.02 & 0.94 & $\begin{array}{c}143 \\
72.2 \%\end{array}$ & $\begin{array}{c}9 \\
4.5 \%\end{array}$ \\
\hline Crop Development & $\begin{array}{c}7 \\
3.5 \%\end{array}$ & $\begin{array}{c}11 \\
5.6 \%\end{array}$ & $\begin{array}{c}44 \\
22.2 \%\end{array}$ & $\begin{array}{c}54 \\
27.3 \%\end{array}$ & $\begin{array}{c}82 \\
41.4 \%\end{array}$ & 3.97 & 1.09 & $\begin{array}{c}136 \\
68.7 \%\end{array}$ & $\begin{array}{c}18 \\
9.1 \%\end{array}$ \\
\hline $\begin{array}{l}\text { Early Warning about } \\
\text { Weather and Climate } \\
\text { Information }\end{array}$ & $\begin{array}{c}4 \\
2 \%\end{array}$ & $\begin{array}{c}4 \\
2 \%\end{array}$ & $\begin{array}{c}30 \\
15.2 \%\end{array}$ & $\begin{array}{c}58 \\
29.3 \%\end{array}$ & $\begin{array}{c}102 \\
51.5 \%\end{array}$ & 4.26 & 0.93 & $\begin{array}{c}160 \\
80.8 \%\end{array}$ & $\begin{array}{c}8 \\
4 \%\end{array}$ \\
\hline $\begin{array}{l}\text { Daily and Seasonal } \\
\text { Weather Forecasts }\end{array}$ & $\begin{array}{c}6 \\
3 \%\end{array}$ & $\begin{array}{c}4 \\
2 \%\end{array}$ & $\begin{array}{c}45 \\
22.7 \%\end{array}$ & $\begin{array}{c}60 \\
30.3 \%\end{array}$ & $\begin{array}{c}83 \\
41.9 \%\end{array}$ & 4.06 & 1 & $\begin{array}{c}143 \\
72.2 \%\end{array}$ & $\begin{array}{c}10 \\
5.1 \%\end{array}$ \\
\hline $\begin{array}{l}\text { Proper Guidelines or } \\
\text { Suggestion }\end{array}$ & $\begin{array}{c}6 \\
3 \%\end{array}$ & $\begin{array}{l}3 \\
1.5 \%\end{array}$ & $\begin{array}{c}29 \\
14.6 \%\end{array}$ & $\begin{array}{c}70 \\
35.4 \%\end{array}$ & $\begin{array}{c}90 \\
45.5 \%\end{array}$ & 4.19 & 0.95 & $\begin{array}{c}160 \\
80.8 \%\end{array}$ & $\begin{array}{c}9 \\
4.5 \%\end{array}$ \\
\hline
\end{tabular}

*Scale: 1 = Strongly Not Needed, 2 = Not Needed, 3 = Not Sure, 4 = Needed, 5 = Strongly Needed

Among different types of information related supports, farmers mostly expect early warning system for the changes in climate factors, accurate and timely forecasting system, 
and proper guidelines and suggestions to cope with climate change properly. Better information system for early warning about changes in climate factors is considered as important by $80.8 \%$ of the farmers, while only $4 \%$ deny it. Moreover, $72.2 \%$ of the farmers agree that weather forecast is also important to adapt to climate change, whereas only $5.1 \%$ feel it is not necessary to cope with climate change. The highest number of farmer $(80.8 \%)$ expects proper guidelines and suggestions to adapt to climate change properly, whereas only $4.5 \%$ feel that these are not needed for adaptation with climate change.

Among the financial and other relevant external supports from government, NGOs and other local and international agencies, raw materials subsidy, cash incentive, insurance or minimum income protection etc are important to cope with climate change. Raw materials subsidy and cash incentive are necessary and needed for $79.8 \%$ of the farmers to cope with climate change impacts, whereas $7.6 \%$ do not need it. Among those who need raw materials subsidy, 54\% emphasized it as very important, and among those who need cash incentive 47\% mentioned that it is very important to cope with climate change. Moreover, $78.3 \%$ emphasized on insurance supports or minimum income ensuring supports to adapt to climate change whereas only $4 \%$ feel it is not necessary.

Table 4: Required Financial and Infrastructural Supports for Adaptation to Climate Change

\begin{tabular}{|c|c|c|c|c|c|c|c|c|c|}
\hline \multirow{2}{*}{$\begin{array}{l}\text { Types of } \\
\text { Supports }\end{array}$} & \multicolumn{5}{|c|}{ Observation Scale* } & \multirow{2}{*}{$\begin{array}{c}\text { Average } \\
\text { Value } \\
\text { of Scale }\end{array}$} & \multirow{2}{*}{ S.D. } & \multirow{2}{*}{$\begin{array}{c}\text { Agreed } \\
\text { (4 and 5) } \\
\text { Observation }\end{array}$} & \multirow{2}{*}{$\begin{array}{c}\text { Disagreed } \\
\text { (1 and 2) } \\
\text { Observation }\end{array}$} \\
\hline & 1 & 2 & 3 & 4 & 5 & & & & \\
\hline Raw materials subsidy & $\begin{array}{c}5 \\
2.5 \%\end{array}$ & $\begin{array}{c}10 \\
5.1 \%\end{array}$ & $\begin{array}{c}25 \\
12.6 \%\end{array}$ & $\begin{array}{c}51 \\
25.8 \%\end{array}$ & $\begin{array}{l}107 \\
54 \%\end{array}$ & 4.24 & 1.02 & $\begin{array}{c}158 \\
79.8 \%\end{array}$ & $\begin{array}{c}15 \\
7.6 \%\end{array}$ \\
\hline Cash Incentive & $\begin{array}{c}7 \\
3.5 \%\end{array}$ & $\begin{array}{c}8 \\
4 \%\end{array}$ & $\begin{array}{c}25 \\
12.6 \%\end{array}$ & $\begin{array}{c}65 \\
32.8 \%\end{array}$ & $9347 \%$ & 4.16 & 1.03 & $\begin{array}{c}158 \\
79.8 \%\end{array}$ & $\begin{array}{c}15 \\
7.6 \%\end{array}$ \\
\hline Insurance Support & $\begin{array}{c}7 \\
3.5 \%\end{array}$ & $\begin{array}{c}1 \\
0.5 \%\end{array}$ & $\begin{array}{c}35 \\
17.7 \%\end{array}$ & $\begin{array}{c}83 \\
41.9 \%\end{array}$ & $\begin{array}{c}72 \\
36.4 \%\end{array}$ & 4.07 & 0.94 & $\begin{array}{c}155 \\
78.3 \%\end{array}$ & $\begin{array}{c}8 \\
4 \%\end{array}$ \\
\hline $\begin{array}{l}\text { Infrastructural } \\
\text { Support, such as } \\
\text { Irrigation, } \\
\text { Transportation }\end{array}$ & $\begin{array}{c}7 \\
3.5 \%\end{array}$ & $\begin{array}{c}5 \\
2.5 \%\end{array}$ & $\begin{array}{c}30 \\
15.2 \%\end{array}$ & $\begin{array}{c}43 \\
21.7 \%\end{array}$ & $\begin{array}{c}113 \\
57.1 \%\end{array}$ & 4.26 & 1.04 & $\begin{array}{c}156 \\
78.8 \%\end{array}$ & $\begin{array}{c}12 \\
6.1 \%\end{array}$ \\
\hline
\end{tabular}

*Scale: 1 = Strongly Not Needed, 2 = Not Needed, 3 = Not Sure, 4 = Needed, 5 = Strongly Needed

Among different encouraging relevant supports, proper infrastructural supports, such as transportation and irrigation, are important for farmers to adapt to changes in climate factors. $78.8 \%$ of the farmers agreed with the necessity of infrastructure related supports whereas $6.1 \%$ mentioned that it is not at all important.

Among the production practices, related supports, diversified crop types and varieties of crops, change land usage patterns, change wage and leasing system, and merge individual farmers to farms are important supports to enable farmers adjust to climate changes. Many farmers $(27.3 \%)$ think diversifying crop types and varieties of crops are not necessary to cope with climate change, whereas $51 \%$ need this support to adapt to climate change. $71.7 \%$ agree to emphasize on land usage pattern to cope with climate change whereas only $5.6 \%$ deny it.

Table 5: Production Practice Relevant Required Supports for Adaptation to Climate Change 


\begin{tabular}{|c|c|c|c|c|c|c|c|c|c|}
\hline \multirow{2}{*}{ Types of Supports } & \multicolumn{5}{|c|}{ Observation Scale* } & \multirow{2}{*}{$\begin{array}{c}\text { Average } \\
\text { Value } \\
\text { of Scale }\end{array}$} & \multirow{2}{*}{ S.D. } & \multirow{2}{*}{$\begin{array}{c}\text { Agreed } \\
(4 \text { and 5) } \\
\text { Observation } \\
\end{array}$} & \multirow{2}{*}{$\begin{array}{c}\text { Disagreed } \\
(1 \text { and } 2) \\
\text { Observation } \\
\end{array}$} \\
\hline & 1 & 2 & 3 & 4 & 5 & & & & \\
\hline $\begin{array}{l}\text { Diversify Crop Types } \\
\text { and Varieties }\end{array}$ & $\begin{array}{c}6 \\
3 \%\end{array}$ & $\begin{array}{c}48 \\
24.2 \%\end{array}$ & $\begin{array}{c}43 \\
21.7 \%\end{array}$ & $\begin{array}{c}31 \\
15.7 \%\end{array}$ & $\begin{array}{c}70 \\
35.4 \%\end{array}$ & 3.56 & 1.28 & $\begin{array}{c}101 \\
51 \%\end{array}$ & $\begin{array}{c}54 \\
27.3 \%\end{array}$ \\
\hline $\begin{array}{l}\text { Adjustment in Land } \\
\text { Use Pattern }\end{array}$ & $\begin{array}{c}5 \\
2.5 \%\end{array}$ & $\begin{array}{c}6 \\
3 \%\end{array}$ & $\begin{array}{c}45 \\
22.7 \%\end{array}$ & $\begin{array}{c}63 \\
31.8 \%\end{array}$ & $\begin{array}{c}79 \\
39.9 \%\end{array}$ & 4.04 & 0.99 & $\begin{array}{c}142 \\
71.7 \%\end{array}$ & $\begin{array}{c}11 \\
5.6 \%\end{array}$ \\
\hline $\begin{array}{l}\text { Adjustment in Wage } \\
\text { and Leasing System }\end{array}$ & $\begin{array}{c}7 \\
3.5 \%\end{array}$ & $\begin{array}{c}9 \\
4.5 \%\end{array}$ & $\begin{array}{c}37 \\
18.7 \%\end{array}$ & $\begin{array}{c}46 \\
23.2 \%\end{array}$ & $\begin{array}{c}99 \\
50 \%\end{array}$ & 4.12 & 1.09 & $\begin{array}{c}145 \\
73.2 \%\end{array}$ & $\begin{array}{c}16 \\
8.1 \%\end{array}$ \\
\hline $\begin{array}{l}\text { Merge Individual } \\
\text { Farmers to Farm }\end{array}$ & $\begin{array}{c}7 \\
3.5 \%\end{array}$ & $\begin{array}{c}17 \\
8.6 \%\end{array}$ & $\begin{array}{c}33 \\
16.7 \%\end{array}$ & $\begin{array}{c}70 \\
35.4 \%\end{array}$ & $\begin{array}{c}71 \\
35.9 \%\end{array}$ & 3.91 & 1.09 & $\begin{array}{c}141 \\
71.2 \%\end{array}$ & $\begin{array}{c}24 \\
12.1 \%\end{array}$ \\
\hline
\end{tabular}

*Scale: 1 = Strongly Not Needed, 2 = Not Needed, 3 = Not Sure, 4 = Needed, 5 = Strongly Needed

$73.2 \%$ of the farmers mentioned that the leasing system and agricultural wage are important factors toward adaptation to climate change, whereas only $8.1 \%$ say it is not important. To adapt to climate change, $71.2 \%$ of the farmers think individual farmers need to merge into single, large farms, whereas $12.1 \%$ do not agree.

Among different types of external supports, the farmers setup the priority of supports based on the importance of each categorical support to adapt to climate change. Farmers firstly need financial and encouraging supports that agreed by $41.9 \%$. Secondly, they need information related supports that agreed by $32.3 \%$. Thirdly, they need resource management innovation related supports, agreed by $31.3 \%$. Fourthly, they need crop development related supports, agreed by $33.8 \%$. Finally, they need production practice related supports that agreed by $43.4 \%$. The priority is setup based on the highest number of choice for each category differs among farmers based on individual necessities. So, adaptation supports for climate change need to be a holistic approach from all aspects to serve farmers to cope with changing factors of climate in better ways.

Table 6: Priority of Required Supports for Adaptation to Climate Change

\begin{tabular}{|c|c|c|c|c|c|c|}
\hline \multirow{2}{*}{$\begin{array}{l}\text { Types of } \\
\text { Supports }\end{array}$} & \multicolumn{5}{|c|}{ Priority Position } & \multirow{2}{*}{$\begin{array}{c}\text { Average Value } \\
\text { of Scale* }\end{array}$} \\
\hline & 1 & 2 & 3 & 4 & 5 & \\
\hline Financial and & 83 & 34 & 39 & 34 & 8 & 2.24 \\
\hline Encouraging & $41.9 \%$ & $17.2 \%$ & $19.7 \%$ & $17.2 \%$ & $4 \%$ & (1) \\
\hline Information & 51 & 64 & 32 & 33 & 18 & 2.51 \\
\hline System & $25.8 \%$ & $32.3 \%$ & $16.2 \%$ & $16.7 \%$ & $9.1 \%$ & (2) \\
\hline Resource Management & 35 & 41 & 62 & 21 & 39 & 2.94 \\
\hline Innovations & $17.7 \%$ & $20.7 \%$ & $31.3 \%$ & $10.6 \%$ & $19.7 \%$ & (3) \\
\hline Crop & 14 & 34 & 36 & 67 & 47 & 3.5 \\
\hline Development & $7.1 \%$ & $17.2 \%$ & $18.2 \%$ & $33.8 \%$ & $23.7 \%$ & (4) \\
\hline Production & 15 & 25 & 29 & 43 & 86 & 3.81 \\
\hline Practices & $7.6 \%$ & $12.6 \%$ & $14.6 \%$ & $21.7 \%$ & $43.4 \%$ & (5) \\
\hline
\end{tabular}

*Priority position is given in the parenthesis.

\section{Conclusion and Policy Recommendations}

In Malaysia, farmers take several types of external supports to adapt to the climate change, especially the paddy producing farmers under the IADA area, but in many cases, farmers are not able to adapt to climatic changes. Here, sustainability of agriculture and relevant 
livelihood is strongly dependent on the subsidy. To adapt to climate change, farmers also need many extra supports relevant with farming practices such as, water management innovation (required for $70.7 \%$ of farmers), irrigation system innovation (required for $70.2 \%$ of farmers), moisture deficiency protection related innovation (required for $72.2 \%$ of farmers), develop new crops or find out varieties of crops or innovation of climate changes tolerant crops (required for $68.7 \%$ of farmers), better information system for early warning (required for $80.8 \%$ of farmers) and forecast climate factors (required for $72.2 \%$ of farmers), irrigation infrastructure supports (required for $78.8 \%$ of farmers), diversify crops types (required for $51 \%$ of farmers), change land usage patterns (required for $71.7 \%$ of farmers), change land leasing system (required for $73.2 \%$ of farmers), price subsidy for input cost(required for $79.8 \%$ of farmers), and provide free raw materials - fertilizer, pesticide, insecticide, fungicide, rodenticide, seed etc. Moreover, farmers also strongly expect supports that are related to socioeconomic adaptation towards climate change such as, cash incentives (required for $79.8 \%$ farmers), insurance or minimum income protection (required for $78.3 \%$ farmers), transportation infrastructure supports (required for $78.8 \%$ farmers), guideline or suggestions (required for $80.8 \%$ farmers), change agricultural wage system (required for $73.2 \%$ farmers), merge individuals to farms (required for $71.2 \%$ farmers), health facilities, and education facility especially related to training opportunity etc.

Among different types of external supports, farmers also setup the priority position of supports based on the importance of each categorical support to adapt to climate change. Most of the farmers need the supports in this order - (i) financial and encouraging supports, (ii) information related supports, (iii) resource management innovation relevant supports, (iv) crop development related supports, and (v) production practice relevant supports. The supports that are mostly relevant to both socioeconomic and farming adaptations have higher priority rather than only agricultural adaptation related support. Among all the required supports, current adaptation ability of farmers is significantly related with the moisture deficiency relevant innovations, crop development, cash incentive, infrastructural supports, and adjustment in wage and leasing system. However, the necessity of extra supports, in respect of their current ability to adapt, shows very low odd ratio. It indicates that these expected supports are not influencing the farmers' current adaption ability. These supports relate to their future adaptation ability that is indicated by individual requirements of supports.

As climate change is a continuous and long-term process, its effects and solutions are similarly time and effort consuming processes. In recent years, adaptation has gained prominence as an essential response measure, especially for vulnerable countries due to the fact that some impacts are now unavoidable in the short to medium term. Immediate and long-term actions are essential for various actors including government, development partners, research organizations, and community organizations. In fact, adaptation is too broad to attribute its costs clearly, because it needs to be undertaken at many levels, including at the household and community level, and many of these initiatives are self-funded (Stern 2007). Government as the policy and law making authority has to play the most influential role to ensure climatic mitigation and adaptation occurs at all levels. It is the main responsibility of the government to give enough support in order to enable farmers to adapt to different climatic situations and to make them self sufficient rather than subsidy dependent (Alam et al. 2010e, 2011e, 2012). Appropriate authorities also need to carefully define government's subsidy supports and incentive programmes to influence farm-level production, practices, and financial management. Hence, agricultural policies and investments need to be more strategic. However, the government needs to define and ensure the compensation, 
minimum income protection, and insurance facility for the affected groups - individual farmer or farm. In the planning processes, policy makers need to account for the barriers of adaptation including ecological, financial, institutional, and technological barriers, as well as information and cognitive hurdles. To avoid the negative impacts of climate changes on agriculture and to control pollutions and emissions in the sector, however, proper mitigation policies are urgently required for Malaysia. Further, Malaysian agriculture sector also needs to include mitigation policies due to the emission of commercial farming.

The issues of mitigation and adaptation to climate change concern all sectors as well as all levels of political, administrative, economic, and everyday life. To better cope, cooperation is necessary across countries, sectors, and administrative levels. Relevant actors are needed to be aware of the benefits of cooperation to gain long-term benefits instead of focusing only on short-term and individual interest. The production practices of farms and the knowledge of individual farmers also need to be updated with the changes of climate factors. The agricultural farmers should understand crop rotation, crop portfolio, and crop substitutions. They should also take all precautions and be aware about the uncertainty of low rainfall and heavy rainfall. The financial management of agricultural farms must be efficient and the farmers must secure a minimum of two cropping seasons so that if crops are damaged in one season, they will have the seeds for the next season. This will help them bear the cost of another crop production and survive financially up to the time when new crops are collected. However, this will require the farmers to take initiatives for crop sharing, forward rating, hedging, and insurance etc.

On the basis of several requirements of farmers, however, the IADA authorities also need to engage different groups of new stakeholders to ensure necessary facilities for the farmers. They also need to engage financial institutions more inclusively in order to provide supports of loan, insurance, saving schemes, hedging or future option, and so on to the agricultural farmers. Technological adaptation to climate change is also important to deal with the climatic problems in the long run. It is apparent that development of technology is a boundless area, but it is possible in several ways. Technology needs to develop to solve the problem such as controlling the pattern of rainfall, sunshine, or to improve shielding resources such as, protect crops from excessive rainfall, solve water logging problems, or to develop defensive approaches such as, varieties of crops development, rainfall and temperature tolerant plants, or to find alternative approaches such as, changing crop cycles, and reducing the timing of crop cycles.

\section{References}

Agriculture Statistical Handbook (2008). Paddy. Ministry of Agriculture. Malaysia.

Alam MM, Siwar C, and Toriman ME (2010a). Socioeconomic Study of Climate Change: An Assessment of Agriculture and Livelihood Sustainability on Paddy Farming in Malaysia. LAP Lambert, Saarbrucken.

Alam MM, Siwar C, Murad MW, Molla RI, and Toriman ME (2010b). Socioeconomic Profile of Farmer in Malaysia: Study on Integrated Agricultural Development Area in North-West Selangor. Agricultural Economics and Rural Development 7(2):249-26. ftp://www.ipe.ro/RePEc/iag/iag_pdf/AERD1013_249-265.pdf Cited 05 Nov 2011

Alam MM, Talib B, Siwar C, and Toriman ME (2010c). The Impacts of Climate Change on Paddy Production in Malaysia: Case of Paddy Farming in North-West Selangor. Proceedings of the international conference of the 4th International Malaysia- 
Thailand Conference on South Asian Studies. National University of Malaysia, Malaysia, Mar 25-26

Alam MM, Siwar C, Molla RI, Toriman ME, and Talib B (2010d). Socioeconomic Impacts of Climatic Change on Paddy Cultivation: An Empirical Investigation in Malaysia. Journal of Knowledge Globalization 3(2):71-84. http://journals.sfu.ca/jkg/index.php/journal/article/view/57/44 Cited 05 Nov 2011

Alam MM, Siwar C, and Al-Amin AQ (2010e). Climate Change Adaptation Policy Guidelines for Agricultural Sector in Malaysia. Asian Journal of Environmental and Disaster Management 2(4):463- 469. DOI 10.3850/S1793924011000873 Cited 05 Nov 2011

Alam MM, Toriman ME, Siwar C, and Talib B (2011a). Rainfall variation and changing pattern of agricultural cycle. American Journal of Environmental Science 7:82-89. DOI 10.3844/ajessp.2011.82.89 Cited 05 Nov 2011

Alam MM, Siwar C, Molla RI, Toriman ME, and Talib B (2011b). Climate Change and Vulnerability of Paddy Cultivation in North-West Selangor, Malaysia: A Survey of Farmers' Assessment. Voice of Academia 6(1):45-56.

Alam MM, Siwar C, Talib B, and Toriman ME (2011c). An Empirical Study on the Relationships between the Socioeconomic Profile of Farmers and Paddy Productivity in North-West Selangor, Malaysia. Asia-Pacific Development Journal 18(1). http://www.unescap.org/pdd/publications/apdj-18-1/5-Alam-and-others.pdf Cited 05 Nov 2011

Alam MM, Toriman ME, Siwar C, Molla RI, and Talib B (2011d). The Impacts of Agricultural Supports for Climate Change Adaptation: Farm Level Assessment Study on Paddy Farmers. American Journal of Environmental Sciences 7(2): 178-182. DOI: 10.3844/ajessp.2011.82.89 Cited 05 Nov 2011

Alam, MM, Siwar C, Murad MW, and Toriman ME (2011e). Impacts of Climate Change on Agriculture and Food Security Issues in Malaysia: An Empirical Study on Farm Level Assessment. World Applied Sciences Journal 14(3): 431-442. http://idosi.org/wasj/wasj14(3)11/12.pdf Cited 05 Nov 2011

Alam, MM, Toriman ME, Siwar, C, and Talib, B (2011f). Paddy Farmers' Adaptation Practices to Climatic Vulnerability in Malaysia, Mitigation and Adaptation for Global Change, DOI: 10.1007/s11027-011-9333-7 Cited 05 Nov 2011

Alam, MM, Siwar, C, Talib, B, Mokhtar, M, and Mohd Ekhwan, T (2012). Climate Change Adaptation Policy in Malaysia: Issues for Agricultural Sector, African Journal of Agricultural Research, Vol. 7(9), pp. 1368-1373. DOI: 10.5897/AJARX11.030 Cited 08 Mar 2012

Baker JT, Allen Jr LH (1993). Contrasting crop species responses to $\mathrm{CO}_{2}$ and temperature: rice, soybean and citrus, Vegetatio, Vol. 104/105, pp. 239-260. (online) http://www.jstor.org/pss/20029749 Cited 05 Nov 2011

Downing TE, Ringius L, Hulme M, Waughray D (1997). Adapting to climate change in Africa, Mitigation and Adaptation Strategies for Global Change, Vol. 2, pp. 19-44. (online) http://www.africaadapt.net/aa/uploads/Resources/7b79b1db63dc45b6b2d24ac0c5171d62_Adapting\%2 0to\%20climate\%20change\%20in\%20Africa.pdf Cited 05 Nov 2011

NAHRIM (2006). Final Report: Study of the Impact of Climate Change on the hydrologic Regime and Water Resources of Peninsular Malaysia, National Hydraulic Research Institute of Malaysia (NAHRIM) and California Hydrologic Research Laboratory (CHRL), Malaysia. (online) http://www.nahrim.gov.my/download/pksa/RegHCM_PM_Report_9_21_06_Ex\%20v 1.pdf Cited 05 Nov 2011 
Ninth Malaysia Plan (2006). Ninth Malaysia Plan 2006-2010. The Economic Planning Unit, Prime Minister's Department, Putrajaya, Malaysia. (online) http://www.parlimen.gov.my/news/eng-ucapan_rmk9.pdf Cited 05 Nov 2011

NRS (2001). National Response Strategies to Climate Change. Ministry of Science, Technology and the Environment, Malaysia. (online) http://gedung.nahrim.gov.my/wapi/mctweb.dll/getObject?MID=WATER\%20RESOU

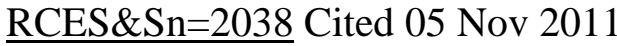

Singh S, Amartalingam R, Wan Harun WS, Islam MT (1996). Simulated impact of climate change on rice production in Peninsular Malaysia, Proceeding of National Conference on Climate Change, pp. 41-49, UPM, Malaysia.

Siwar C, Alam MM, Murad MW, Al-amin AQ (2009). A review of the linkages between climate change, agricultural sustainability and poverty in Malaysia, International Review of Business Research Papers, Vol. 5(6), pp. 309-321. (online) http://www.bizresearchpapers.com/23.\%20Siwar.pdf Cited 05 Nov 2011

Stern N (2007). The Economics of Climate Change: The Stern Review. Cambridge: Cambridge University Press.

Tashiro T, Wardlaw IF (1989). A comparison of the effect of high temperature on grain development in wheat and rice, Annals of Botany, Vol. 64, pp. 59-65. (online) http://aob.oxfordjournals.org/content/64/1/59.full.pdf Cited 05 Nov 2011

Tisdell C (1996). Economic indicators to assess the sustainability of conservation farming projects: An evaluation. Agriculture, Ecosystems and Environment, Vol. 57(2), pp. 117-131. http://www.sciencedirect.com/science/article/pii/0167880996010171 Cited 05 Nov 2011 